\title{
PERANAN GURU MEMILIH MODEL-MODEL PEMBELAJARAN UNTUK MENINGKATKAN KEMAMPUAN MENULIS PUISI
}

\author{
Rencus B. Sinabariba \\ Surel: rencus82@yahoo.com
}

\begin{abstract}
Abstrak
Tujuan dari penelitian yaitu 1) Untuk mengetahui apa saja jenis-jenis model pembelajaran untuk meningkatkan kemampuan menulis puisi bagi siswa;

Bagaimana hasil kemampuan menulis puisi siswa setelah guru menerapkan model-model pembelajaran tersebut. Penelitian ini merupakan penelitian deskriptif kualitatif, peneliti mengambil data dari sumber pustaka dan sumber-sumber yang terkait. Kemampuan menulis puisi yang dimiliki siswa saat ini masih belum maksimal. Hal ini dapat dikembangkan oleh guru dengan menerapkan model pembelajaran yang sesuai. Adapun model-model pembelajaran yang dapat diterapkan adalah sebagai berikut: Model Partisipatory dengan Media Gambar, Copy The Master dengan Bantuan VCD Berbasis Pendidikan Karakter, Quantum Teaching Tipe Tandur. Ketiga model belajar tersebut sudah diterapkan di beberapa sekolah yang telah diteliti oleh para peneliti sebelumnya dan dipublikasikan dalam jurnal. Hasil yang didapatkan dari penelitian-penelitian tersebut sangat baik sehingga layak menjadi bahan referensi dan pertimbangan bagi setiap guruguru di Indonesia sehingga dapat diterapkan di sekolah masing-masing.
\end{abstract}

Kata Kunci : Puisi, Partisipatory, Copy The Master, Quantum Teaching

\begin{abstract}
Abstrack
The purpose of the research is 1) To know what kinds of learning models to improve the ability to write poetry for students; (2) How is the result of students' poetry writing ability after the teacher apply the learning models. This research is descriptive qualitative research, researcher take data from source of libraries and related sources. The ability to write poetry owned by students is still not maximized. This can be developed by teachers by applying appropriate learning models. The learning models that can be applied are as follows: Participatory Model with Image Media, Copy The Master with VCD-Based Character Education Assistance, Quantum Teaching Type Tandur. The three learning models have been applied in several schools that have been researched by previous researchers and published in the journal. The results obtained from these studies are so good that it deserves to be a reference and consideration for every teacher in Indonesia so that it can be applied in each school.
\end{abstract}

Keywords : Poetry, Partisipatory, Copy The Master, Quantum Teaching

Pasca Sarjana Universitas Negeri Medan 


\section{PENDAHULUAN}

Menulis merupakan salah satu kemampuan berbahasa yang harus dimiliki oleh setiap siswa agar proses belajar dapat berjalan dengan baik. Kemampuan menulis sangat penting dimiliki siswa karena kemampuan ini merupakan proses mengeluarkan ide maupun gagasan dalam bentuk tulisan. Hal ini segayut dengan pendapat (Gie, 2002:9) "Menulis adalah segenap rangkaian kegiatan seseorang mengungkapkan buah pikirannya melalui bahasa tulis untuk dibaca dan dimengerti oleh orang lain. Buah pikiran itu dapat berupa gagasan, pikiran, pengalaman, ataupun imajinasi seseorang”. Keterampilan menulis merupakan keterampian yang dapat diasah dengan berbagai latihan secara intensif. Dalam pembelajaran di sekoah keterampilan menulis harus dikuasai oleh siswa, salah satunya adalah keterampilan menulis puisi.

Keterampilan menulis puisi merupakan materi yang sudah diajarkan kepada siswa baik ditingkat sekolah dasar maupun menengah. Kemampuan ini sangat penting dikuasai oleh siswa karena memberikan banyak manfaat bagi perkembangan siswa itu sendiri.

Proses kreatif menulis puisi memberikan hasil yang positif bagi para siswa. Dengan menulis puisi, siswa dilatih untuk tidak meremehkan pengalamanpengalamannya. Segala sesuatu yang dilihat dan dialaminya selalu tidak luput dari perhatiannya. Dia menjadikan semua yang dilihat, didengar, dan dirasa sebagai sesuatu yang bermakna bagi manusia. Wujud perhatian dan usaha menjadikan pengalaman-pengalaman itu sebagai sesuatu yang bermakna bagi manusia di antaranya adalah menuangkan atau menuliskan apa yang dialaminya ke dalam bentuk puisi (Jabrohim dkk, 2003: 31).

Pembelajaran menulis puisi merupakan pembelajaran menuangkan ide/gagasan dalam bentuk kata-kata yang indah atau berupa ekspresi sastra. Pembelajaran ini mengarahkan siswa untuk menuangkan imajinasinya dalam bentuk puisi. Proses ini dapat berjalan dengan baik jika proses pembelajaran terhadap materi ini dapat dikuasai oleh siswa dan guru dapat memberikan pembelajaran yang baik.

Seorang guru sebelum masuk kelas untuk memberikan materi pembelajaran haruslah ada persiapan. Guru harus mengetahui apa yang menjadi tujuan dari materi yang diajarkannya. Untuk itu, guru juga harus mengetahui model-model pembelajaran yang sesuai diterapkan saat akan mengajar, seperti dalam hal mengajar keterampilan menulis puisi.

Model pembelajaran dapat diartikan sebagai prosedur sistematis dalam mengorganisasikan pengalaman belajar untuk mencapai tujuan belajar. Dapat juga diartikan suatu pendekatan yang digunakan dalam kegiatan pembelajaran. model pembelajaran memiliki arti yang sama dengan pendekatan, strategi atau metode pembelajaran. Saat ini telah banyak dikembangkan berbagai macam model pembelajaran, dari yang sederhana sampai model yang agak kompleks dan rumit karena memerlukan banyak alat bantu dalam penerapannya. 
Sebagai seorang guru harus mampu memilih model pembelajaran yang tepat bagi peserta didik. Karena itu dalam memilih model pembelajaran, guru harus memperhatikan keadaan atau kondisi siswa, bahan pelajaran serta sumbersumber belajar yang ada agar penggunaan model pembelajara dapat diterapkan secara efektif dan menunjang keberhasilan belajar siswa.

Seorang guru diharapkan memiliki motivasi dan semangat pembaharuan dalam proses pembelajaran yang dijalaninya. Hal ini senada dengan pendapat Sardiman A. M. (2004 : 165), guru yang kompeten adalah guru yang mampu mengelola program belajar-mengajar. Mengelola di sini memiliki arti yang luas yang menyangkut bagaimana seorang guru mampu menguasai keterampilan dasar mengajar, seperti membuka dan menutup pelajaran, menjelaskan, menvariasi media, bertanya, memberi penguatan, dan sebagainya, juga bagaimana guru menerapkan strategi, teori belajar dan pembelajaran, dan melaksanakan pembelajaran yang kondusif.

Pendapat serupa dikemukakan oleh Colin Marsh (1996 : 10) yang menyatakan bahwa guru harus memiliki kompetensi mengajar, memotivasi

peserta didik, membuat model instruksional, mengelola kelas, berkomunikasi, merencanakan pembelajaran, dan mengevaluasi. Semua kompetensi tersebut mendukung keberhasilan guru dalam mengajar.

Semua model-model pembelajaran yang digunakan guru saat akan mengajar akan memberikan hasil yang baik jika diterapkan dengan baik, khususnya modelmodel belajar yang akan digunakan untuk meningkatkan kemampuan menulis puisi. Guru harus mengetahui apa yang menjadi tujuan belajar dari pembelajaran keterampilan menulis puisi, yaitu siswa harus dapat menulis puisi. Untuk itu guru memiliki peranan yang sangat penting dalam memilih model-model belajar yang sesuai untuk meningkatkan keterampilan menulis puisi bagi siswa.

Berdasarkan uraian-uraian di atas penulis akan menguraikan Peranan Guru Memilih Model-Model Pembelajaran untuk Meningkatkan Kemampuan Menulis Puisi. Adapun rumusan-rumusan masalah yang akan diuraikan dalam penelitian ini adalah (1) Apa saja model-model pembelajaran untuk meningkatkan kemampuan menulis puisi; (2) Bagaimana kemampuan menulis puisi siswa setelah menerapkan model-model pembelajaran tersebut.

Adapun yang menjadi tujuan dari penelitian ini adalah untuk mengetahui Apa saja jenis-jenis model pembelajaran untuk meningkatkan kemampuan membaca siswa dan bagaimana hasil kemampuan membaca siswa setelah menerapkan model-model tersebut. Penelitian ini diharapkan memberikan manfaat bagi peneliti, guru, siswa, maupun bagi peneliti yang lain. 


\section{PEMBAHASAN}

\section{1) Model-Model Pembelajaran Untuk Meningkatkan Kemampuan Siswa Dalam Menulis Puisi}

Proses belajar mengajar di dalam kelas akan lebih efektif dan bermakna jika seorang guru yang akan mengajar terlebih dahulu mempersiapkan materi. Materi yang akan disampaikan terhadap peserta didik haruslah dengan mudah dapat dipahami siswa sehingga apa yang diharapkan dari peserta didik akan tercapai. Selain persiapan materi yang mau diajarkan guru yang akan mengajar juga harus mengetahui model pembelajaran yang sesuai untuk materi yang akan diajarkan kepada siswa.

Penggunaan model pembelajaran yang efektif akan memudahkan guru dalam mengajar. Kegiatan pembelajaran juga akan menyenangkan bagi guru maupun peserta didik atau siswa. Model pembelajaran semuanya baik jika digunakan secara tepat. Akan tetapi guru harus cermat daalm memilih model yang sesuai terhadap materi yang akan diajarkan, khususnya materi pembelajaran menulis puisi.

Pembelajaran menulis puisi berkaitan dengan kesusastraan. Pembelajaran ini harus dapat melibatkan siswa agar dapat menuangkan imajinasi dengan kata-kata yang indah, yaitu sebuah puisi. Siswa harus dapat menulis puisi dengan karakter yang diharapkan oleh guru maupun siswa itu sendiri. Untuk itu, guru harus menggunakan model pembelajaran yang sesuai dengan karakter siswa tersebut. Berikut ini akan diuraikan beberapa model belajar untuk meningkatkan kemampuan siswa daalm menulis puisi.

\section{a) Model Quantum Teaching Tipe Tandur}

Model pembelajaran Quantum Teaching merupakan model yang menciptakan lingkungan belajar yang efektif, dengan cara menggunakan unsur yang ada pada siswa dan lingkungan belajarnya melalui interaksi yang terjadi didalam kelas. (Miftahul a'la 2011). Dalam model pembelajaran quantum teaching ada beberapa tipe atau teknik yang dapat diterapkan dalam pembelajaran. Peneliti mencoba menerapkan tipe TANDUR dalam penelitian ini. TANDUR sendiri merupakan akronim dari Tumbuhkan, Alami, Namai, Demonstrasikan, Ulangi dan Rayakan. (Miftahul a'la 2011).

\section{Tumbuhkan}

Tumbuhkan minat dengan memuaskan. Dalam hal ini guru memberikan motivasi, semangat, rangsangan supaya belajar, yaitu dengan melakukan praktek secara langsung apa yang disampaikan oleh guru, diantaranya dengan menyadarkan para siswa bahwa materi yang akan disampaikan (keterampilan menulis puisi) merupakan materi yang benar-benar bermanfaat bagi hidup mereka.

Alami 
Ciptakan atau datangkan pengalaman umum yang dapat dimengerti semua peserta didik. Peserta didik mengalami sendiri apa yang dilakukan dengan praktik langsung dalam menyelesaikan masalah.

Namai

Sediakan kata kunci, konsep, model, rumus, strategi, sebuah masukan. Dengan melakukan praktik secara langsung maka peserta didik benarbenar bisa mencari bagaimana cara menulis puisi dengan alat bantu (media) peserta didik mendapatkan informasi (nama) yaitu dengan pengalaman yang dialami sehingga membuat pengetahuan peserta didik akan berarti.

Demonstrasikan

Guru memberikan peserta didik untuk menunjukkan bahwa mereka tahu. Peserta didik diberi peluang untuk menterjemahkan dan menerapkan pengetahuan mereka dalam pelajaran, sehingga peserta didik bisa menunjukkan dan menyampaikan kemampuan yang telah didapat, dialami sendiri oleh peserta didik. Dengan mendemonstrasikan peserta didik akan mendapatkan kesan yang sangat berharga sehingga terpatri dalam hati.

Ulangi

Tunjukkan peserta didik cara-cara mengulang materi dan menegaskan

"Aku tahu bahwa aku memang tahu ini". Mengulang materi pembelajaran akan menguatkan koreksi saraf dan menumbuhkan rasa tahu dari materi yang telah dialami peserta didik secara langsung, sehingga peserta didik akan selalu teringat dari materi menulis puisi yang telah dialaminya.

Rayakan

Akhiri setiap proses pembelajaran dengan me-rayakan-nya. Prinsip dari rayakan yaitu, "Jika layak dipelajari, maka layak pula dirayakan".

Penghargaan atas karya siswa dapat dilakukan dengan banyak cara, misalnya dengan memilih puisi terbaik, memilih puisi terfavorit, memberi pujian pada seluruh siswa yang ada di kelas itu yang telah menulis puisi (misalnya dengan mengacungkan jempol dan mengucap kata, "Sip! Hebat! Bagus! Cerdas! Pintar! Luar biasa.

\section{Model Partisipatori Dengan Media Gambar}

Model partisipatori adalah model pembelajaran yang lebih menekankan keterlibatan siswa secara penuh. Berbeda dengan metode jelajah alam sekitar yang pembelajarannya harus dilakukan di luar kelas, metode partisipatori dilakukan di dalam kelas dengan bantuan media gambar dan pengalaman. Siswa dianggap sebagai penentu keberhasilan belajar. Dengan berpartisipasi aktif, siswa dapat menemukan hasil belajar. Guru hanya bersifat sebagai pemandu atau fasilitator. 
Begitu juga bentuk partisipasi aktif siswa dalam menulis puisi keindahan alam yaitu ketika siswa dapat menemukan sendiri hal-hal yang berkaitan dengan materi menulis puisi dan mendiskusikannya bersama teman dalam kelompok serta dipandu oleh guru.

Media gambar adalah alat dan bahan yang digunakan dalam proses pengajaran atau pembelajaran yang berupa tiruan barang (orang, binatang, tumbuhan) yang dibuat dalam coretan pensil pada kertas dan lukisan (KBBI 2008). Dengan demikian, media gambar dapat mengembangkan kemampuan visual, mengembangkan imajinasi siswa sehingga membantu siswa menemukan ide dan membantu mengungkapkannya ke dalam puisi serta dapat membangkitkan motivasi dan minat siswa dalam pembelajaran. Selain itu, media gambar juga berfungsi sebagai sarana penunjang dalam menciptakan sebuah puisi yang baik.

Proses pembelajaran dengan model ini menggunakan tiga tahapan saat proses belajar yang dilakukan oleh guru di dalam kelas, yaitu tahap penginderaan, tahap perenungan dan tahap memainkan kata-kata. Ketiga tahapan ini akan dijelaskan sebagai berikut ini.

Para penyair sebelum menciptakan sebuah puisi terlebih dahulu melakukan penginderaan terhadap alam sekitar. Hal ini dilakukan untuk menemukan keindahan yang ada di alam sekitar penyair. Keindahan itulah yang kemudian akan dijadikan sebagai sumber inspirasi dalam puisi. Penginderaan merupakan tahap yang paling menentukan dalam pembelajaran menulis puisi dengan metode partisipatori. Dalam tahap ini siswa dituntut untuk menemukan ide untuk puisinya. Setelah ide ditentukan, maka proses belajar akan berjalan dengan lancar.

Tahap selanjutnya adalah tahap perenungan atau pengendapan. Perenungan ini akan semakin mendalam jika disertai dengan daya intuisi yang tajam, karena dengan daya intuisi akan mampu memunculkan sesuatu yang tidak mungkin menjadi mungkin.

Tahap yang terakhir adalah tahap memainkan kata. Yang harus dilakukan terlebih dahulu adalah mengumpulkan kata-kata yang berhubungan dengan tema yang dipilih, kemudian perlu dilakukan penyeleksian makna kata yang memiliki nilai rasa yang lebih tinggi. Kata-kata yang memiliki nilai rasa yang lebih tinggi itulah yang digunakan dalam menulis puisi.

\section{Model Copy The Master Dengan Bantuan Ved Berbasis Pendidikan Karakter}

Model copy the master merupakan metode meniru atau mencontoh master atau model dari seorang ahli. Dalam pembelajaran menulis, siswa langsung disajikan sebuah contoh tulisan yang paling baik (master) kemudian siswa meniru bentuk tulisan tersebut (Marahimin, 2005:20). 
Model belajar ini dapat diterapkan disekolah menengah dasar maupun atas dengan mengikuti tiga tahapan yang harus diikuti oleh guru di sekolah. Ketiga tahapan tersebut harus dapat dilaksanakan guru dengan baik sehingga hasilnya akan memberikan dampak yang baik pula. Adapun ketiga tahapan itu akan dijelaskan satu-persatu, yakni sebagai berikut.

Tahap pertama proses pembelajaran diawali dengan mengkondisikan siswa agar siap untuk mengikuti pembelajaran menulis puisi dengan menanyakan keadaan siswa, mengadakan kegiatan apersepsi yang diawali dengan memberikan ilustrasi tentang pembelajaran menulis puisi. Kemudian siswa diminta untuk memperhatikan penjelasan yang disampaikan guru. Kegiatan berikutnya yaitu menanyakan pengalaman siswa dalam menulis puisi, dan menyampaikan tujuan serta manfaat pembelajaran menulis puisi. Hal ini dilakukan sebagai upaya menumbuhkan minat belajar siswa agar siswa memiliki motivasi belajar terlebih dahulu. Pada kegiatan tersebut siswa terlihat mulai antusias memperhatikan penjelasan guru.

Tahap kedua disebut dengan eksplorasi, yaitu tahapan ini diawali dengan tanya jawab mengenai pengetahuan dasar tentang puisi (pengertian, ciri- ciri, dan unsur pembangun puisi) yang diketahui oleh siswa. Pada tahap elaborasi, siswa berpasangan dengan teman sebangkunya. Kemudian guru membagikan puisi master kepada tiap pasangan untuk dibaca dan dicermati penulisannya. Selanjutnya guru memutarkan tayangan VCD berbasis pendidikan karakter, siswa diminta untuk mencermati tayangan VCD dan kemudian menulis puisi melalui metode copy the master dengan bantuan tayangan VCD berbasis pendidikan karakter.

Tahap ketiga disebut dengan konfirmasi, yaitu siswa yang ditunjuk guru maju ke depan untuk membacakan hasil puisinya, dan teman yang lain memperhatikan. Kemudian siswa dan guru mendiskusikan hasil pekerjaan siswa. Hasil tes tersebut dijadikan sebagai data dari hasil tulisan siswa. Beberapa siswa mengutarakan kesulitan saat berimajinasi, karena kurang fokus terhadap tayangan VCD yang diputarkan guru. Sebelum pembelajaran selesai, siswa yang menulis puisi dengan baik akan diberikan penghargaan.

\section{SIMPULAN}

Berdasarkan data, analisis, dan pembahasan dalam penelitian ini yang telah diuraikan pada bagian sebelumnya, penulis mengambil simpulan, yaitu (1) Bagi setiap guru di Indonesia agar selalu melakukan persiapan sebelum mengajar, yaitu mengetahui apa yang harus dilakukan di dalam kelas sehingga setiap siswa senang untuk belajar; (2) Guru dapat menerapkan Model Quantum Teaching Tipe Tandur, Model Partisipatori dengan Media Gambar, Dan Model Copy The Master dengan Bantuan VCD Berbasis Pendidikan Karakter untuk meningkatkan kemampuan siswa daalm menulis puisi; (3) Ketiga model yang sudah diuraikan di 
atas merupakan model-model pembelajaran yang sudah diterapkan di beberapa sekolah di Indonesia dan hasilnya sangat baik, siswa mengalami kenaikan dalam mhal penulisan puisi.

Selain model-model belajar yang sudah diuraikan di atas, guru dapat memilih model-model belajar yang lain untuk meningkatkan kemampuan menulis puisi bagi siswa. Untuk itu, guru harus terus berinovasi sehingga mengetahui apa yang dibutuhkan oleh peserta didik. Semoga artikel ini memberikan manfaat bagi peneliti, guru, siswa maupun peneliti lainnya.

Berdasarkan simpulan tersebut, peneliti merekomendasikan saran, yaitu (1) pemerintah harus senantiasa memberikan pelatihan-pelatihan terhadap guru-guru di Indonesia khususnya dalam hal memilih model-model belajar yang sesuai diterapkan oleh guru di kelas; (2) sudah selayaknya guru-guru yang masuk ke dalam kelas agar mempersiapkan perangkat-perangkat pembelajaran yang diperlukan agar proses belajar mengajar di kelas dapat berjalan dengan baik. (3) siswa dan guru yang berprestasi agar mendapatkan perhatian yang khusus dari pemerintah pusat maupun daerah sehingga akan memberikan motivasi yang baik bagi siswa dan guru yang lainnya untuk berprestasi.

\section{DAFTAR RUJUKAN}

Ariani, Farida. 2004. Keterampilan Menulis dan Membaca. Jakarta: Pusat Pengembangan Penataran Guru Bahasa.

Gulo, W. 2002. Strategi Belajar Mengajar. Jakarta: PT Grasindo.

Rusman. 2012. Model-Model Pembelajaran, Jakarta: PT Raja Grafindo.

Umry, Shafwan Hadi. 2016. Telaah Puisi: Pembelajaran dan Penerapan, Medan:

CV Mitra

"Peningkatan Keterampilan Menulis Puisi Keindahan Alam Menggunakan Metode Partisipatori dengan Media Gambar" Jurnal Pendidikan Bahasa

dan Sastra Indonesia (JPBSI) (1), ISSN 2252-6722, http://journal.unnes.ac.id/sju/index.php/jpbsi/ Anisa Nur Laeli dan Wagiran. Diunduh pada Selasa, 03 September 2017 pukul 22.00 WIB.

"Peningkatan Keterampilan Menulis Puisi Melalui Metode Copy The Master dengan Bantuan VCD Berbasis Pendidikan Karakter” Jurnal Pendidikan Bahasa dan Sastra Indonesia, JPBSI 3 (1), http://journal.unnes.ac.id/sju/index.php/jpbsi/ Eva Kristian Andriani, Agus Nuryatin dan Wagiran. Diunduh pada Selasa, 03 September 2017 pukul 23.00 WIB. 
"Peningkatan Keterampilan Menulis Puisi Melalui Model Pembelajaran Quantum Teaching Tipe Tandur" Jurnal Pendidikan Bahasa dan Sastra Indonesia, JPBSI 2 (1), http://journal.unnes.ac.id/sju/index.php/jpbsi/ Muhammad Zulfa Majid. Diunduh pada Selasa, 03 September 2017 pukul 23.40 WIB. 
